\title{
ANALISIS PENDAPATAN PETERNAK USAHA SAPI POTONG DENGAN BERBAGAI POLA TANAM DI KECAMATAN UMBULSARI KABUPATEN JEMBER
}

\author{
Nanang Dwi Wahyono \\ Politeknik Negeri Jember \\ Zainal Fanani \\ Universitas Brawijaya Malang \\ Noer Soetjipto \\ Universitas Muhammadiyah Gresik
}

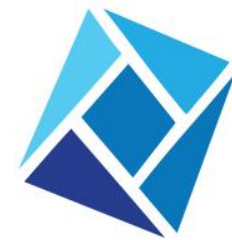

Jurnal Nusantara

Aplikasi Manajemen Bisnis

http://ojs.unpkediri.ac.id/index .php/manajemen/index

E-ISSN : 2528-0929

P-ISSN : 2549 - 5291

Diterima: 31 Maret 2018

Revisi : 16 April 2018

Disetujui: 18 April 2018

https:doi.org10.29407nusamba.v3i1. 12027
Abstact

The purpose of this research is as follows: 1) Analyzing the cost of farming with beef cattle on various cropping patterns, 2) Analyzing the acceptance of farming with beef cattle on various cropping patterns, 3) Analyze the income of farming with beef cattle on various cropping patterns, 4) Analyze the acceptance and cost of farming with beef cattle on various cropping patterns. The sampling frame technique used in this study is a two-stage cluster sampling. Determination of sample and location of research conducted by purposive. Sampling. The analysis model used is the cost analysis and income of crop farming and beef cattle business. The results of the research are as follows: 1) Planting pattern 5 ie sugarcane with the highest cost of beef cattle compared to other cropping pattern per hectare per tail is Rp 96,750 For farming and Rp 10.865.000, - for beef cattle business so that the total cost of crop farming and beef cattle business is Rp 107.615.000, -, 2) Planting pattern 5 that is sugar cane plant with the highest beef cattle receiving business income from the yield of planting pattern 5 per hectare of 110.450.000, - and the business of beef cattle per livestock unit of $R p$ $14,900,000$, - so the amount of receipt is $R p$ 125.350.000, -, 3) The income from the farming cropping 5 is Rp 13.700.000, - and beef cattle breeding business per unit of livestock amounting to Rp 4,035,000, - so the total income of $R p$ 17,735,000, - which is the highest income, 5) $n$ and the cost of planting pattern 4 sebebsar 1.82 is highest.

\section{Abstrak}

Tujuan dari penelitian ini adalah sebagai berikut : 1)Menganalisis Biaya usahatani dengan Sapi potong pada berbagai macam pola tanam, 2) Menganalisis Penerimaan usahatani dengan Sapi potong pada berbagai macam pola tanam, 3) Menganalisis Pendapatan usahatani dengan Sapi potong pada berbagai macam pola tanam, 4) Menganalisis Imbangan penerimaan dan biaya usahatani dengan Sapi potong pada berbagai macam pola tanam. Teknik kerangka sampling yang digunakan dalam penelitian ini adalah sampling cluster dua tingkat (Two Stage Cluster Sampling). Penentuan sampel dan lokasi penelitian dilakukan secara purposive. Sampling. Model analisis yang digunakan adalah analisis biaya dan pendapatan usahatani tanaman dan usaha sapi potong. Hasil penelitian adalah sebagai berikut : 1)Pola tanam 5 yaitu tanaman tebu dengan usaha sapi potong biaya paling tinggi dibandingkan dengan pola tanam lainnya yaitu per hektar per ekor adalah Rp 96.750.000,untuk usahatani dan Rp 10.865.000,- untuk usaha sapi potong sehingga total biaya usahatani tanaman dan usaha sapi potong sebesar Rp 107.615.000,-, 2) Pola tanam 5 yaitu tanaman tebu dengan usaha sapi potong penerimaan paling tinggi yaitu penerimaan dari hasil pola tanam 5 per hektar sebesar 110.450.000,- dan usaha sapi potong per satuan ternak sebesar Rp 14.900.000,sehingga jumlah penerimaan sebesar Rp 125.350.000,-, 3) Pendapatan dari hasil usahatani pola tanam 5 sebesar Rp 13.700.000,- dan usaha sapi potong pembibitan per satuan ternak sebesar Rp 4.035.000,- sehingga jumlah pendapatan Rp 17.735.000,- yang merupakan pendapatan paling tinggi, 5) Tingkat imbangan penerimaan dan biaya pada pola tanam 4 sebebsar 1,82 merupakan paling tinggi.

Kata Kunci : analisis pendapatan, sapi potong, pola tanam 


\section{Pendahuluan}

Sub sektor tanaman pangan dan sub sektor peternakan merupakan satu kesatuan yang terintegrasi keduanya tidak akan terlepas dan saling melengkapi dimana limbah pertanian dapat dimanfaatkan oleh ternak dan pada sisi lain ternak dapat menghasilkan limbah berupa kotoran untuk pupuk tanaman. Basis pembangunan adalah pembangunan pedesaan oleh kerena itu pembangunan pedesaan pada daerah-daerah pemasok produksi pertanian (daerah sentral produksi) melalui pengembangan Daerah Pusat Pertumbuhan (DPP) perlu lebih dimantapkan agar memiliki ketahanan yang lebih kuat mengingat daerah pedesaan sangat penting, terutama dalam hal: (1) penyedia bahan pangan untuk penduduk (termasuk untuk daerah perkotatan), (2) penyedia tenaga kerja untuk pembangunan, (3) penyedia bahan baku untuk industri, serta (4) penghasil komoditi untuk ekspor ke luar negeri. Untuk mempercepat pembangunan pedesaan dan pertanian diperlukan komitmen dan tanggung jawab moral pembangunan dari segenap aparatur pemerintah, masyarakat, maupun swasta, sehingga pembangunan pertanian dapat dilakukan secara efektif, efisien, terintegrasi, dan sinkronisasi dengan pembangunan sektor lainnya dan berwawasan lingkunagan.

Salah satu program keterpaduan antara semua sistem usahatani adalah mengembangkan usaha sapi potong yang dilakukan pada daerah pemasok hasil produksi pertanian melalui pengembangan sapi potong yang diharapkan dapat mendorong, menarik, menghela kegiatan di desa-desa pinggiran (hinterland) dan desa-desa sekitarnya. Produksi peternakan sapi potong selain bahan baku konsumsi pangan juga merupakan bahan baku komoditas ekspor yang perlu digalakkan oleh karena itu akan mempengaruhi struktur perekonomian wilayah. Disamping itu juga pembangunan peternakan membuka kesempatan kerja dan kesempatan berusaha yang dapat mengurangi pengangguran dipedesaan baik pada sektor hulu, hilir maupun sektor pemasaran hasil produksi peternakan.Untuk mendukung kebijakan pembangunan khususnya peternakan sapi potong maka diperlukan informasi dasar, potensi sumberdaya alam dan sumber daya manusia serta sarana pendukung baik yang merupakan kekuatan maupun kelemahan-kelamahan dari sektor peternakan didalam disuatu wilayah, sumbangannya terhadap perekonomian wilayah, prospek pengembangannya yang dapat ditinjau dari aspek ekonomi, sosial budaya serta daya dukung wilayah tersebut. 
Upaya pengembangan ternak sapi potongdi Kabupaten Jemberdilakukan melalui beberapa terobosan antaralain adopsi teknologi peternakan berupa melaksanakan persilangan ternak-ternak lokal dengan ternak yang bersumber dari bibit unggul melalui insiminasi buatan (IB), melakukan pengendalian penyakit, melalukan penyuluhan agar petani memelihara ternak dari sistem pemeliharaan yang digembalakan menjadi dikandangkan, memberikan bantuan modal usaha dengan harapan terjadi perubahan yang ditekankan pada perubahan pendapatan. Meskipun demikian sampai saat ini perkembangan sapi potong masih tetap lamban. Hal ini disebabkan permasalahan yang dihadapi pada usaha peternakan sapi rakyat sangat kompleks antara lain keterbatasan sumberdaya, lahan, modal dan tenaga kerja serta manajeman usahanya.

Dalam usaha ternak sapi potong peternak untuk mencapai tujuan yaitu pendapatan (incomes) dipengaruhi oleh dua faktor yaitu faktor internal dan faktor eksternal. Faktor dari dalam (internal) adalah faktor yang bersumber dari peternak sendiri antara lain umur, pendidikan, pengalaman berternak (lama usaha), jumlah kepemilikan ternak, luas lahan yang dikuasai, jumlah anggota rumahtangga, sedangkan faktor dari luar (eksternal) antara lain tingkat upah tenaga, harga bibit, harga pakan konsentrat dan lain sebagainya. Penelitian ini dilakukan untuk mengetahui tingkat biaya, penerimaan dan pendapatan peternak dengan berbagai pola tanam yang dilakukan petani.

\section{METODE PENELITIAN}

\section{Lokasi Penelitian}

Penelitian ini dilakukan diKecamatan Umbulsari Kabupaten Jember, yang dimulai tanggal 16 Juni 2016 sampai dengan 28 September 2016.

\section{Pengambilan Sampel}

Sesuai dengan tujuan penelitian yang telah dirumuskan di atas, maka penelitian ini mengggnakan metode survei (suvey Method), sesaui dengan yang dikemukakan oleh Singarimbun (1991). Dalam survei ini peneliti tidak mempunyai daftar lengkap seluruh nama-nama petani yang ada di Kecamatan Umbulsari sebagai kerangka sampling. Oleh karena itu kerangka sampling yang digunakan dalam penelitian ini adalah sampling cluster dua tingkat (Two Stage Cluster Sampling

Berdasarkan tujuan dari penelitian ini, maka penentuan sampel dan lokasi penelitian dilakukan secara purposive. Penelitian secara purposive artinya sampel 
dipilih dan ditetapkan dengan berdasarkan pertimbangan-pertimbangan tertentu sesuai dengan tujuan penelitian seperti dikemukakan oleh Singarimbun dan Effendi (1982). Sampel yang diambil adalah sebanyak 32 sampel dengan penyebaran responden desategalwangi 13 Responden, Gunungsari 10 Responden dan Paleran 9 Responden.

\section{Analisis Usahatani dan Sapi Potong}

Model analisis biaya dan pendapatan usahatani tanaman dan usaha sapi potong dengan rumus sebagai berikut :

$$
\pi=o_{i} \stackrel{P}{i}_{i=1}^{n}-I_{j}{ }_{j=1}^{m} P_{j}
$$

Dimana:

$\pi$ : pendapatan dari hasil usahatani tanaman dan usaha sapi potong

$\mathrm{O}$ : output yang dihasilkan dari usahatani tanaman dan usaha sapi potong

I : biaya-biaya yang dikeluarkan untuk usahatani tanaman dan usaha sapi potong

P: harga dari masukan dan keluaran usahatani tanaman dan sapi potong

\section{HASIL PENELITIAN DAN PEMBAHASAN}

\section{Keadaan Umum Usaha Peternakan dan Pola Tanam}

\section{a. Keadaan Usaha Peternakan}

Ternak yang diusahakan oleh penduduk di wilayah kecamatan Umbulsari adalah sangat penting dalam rangka untuk mendukung kegiatan usahatani. Ternak tersebut berfungsi sebagai materi kekayaan dan sebagai tabungan, semakin banyak ternak yang dipelihara berarti semakin besar tabungan yang dmiliki petani. oleh karena itu, program pengembangan dan penyebaran ternak d daerah pedesaan sangat pentrng. Hal ini berkaitan dengan upaya peningkatan poduksi dan peningkatan populasi ternak, penyediaan lapangan kerja, dan menarik modal untuk mengembangkan pedesaan, karena sebagian besar penduduk bertempat tinggal di pedesaan.

Pengembangan peternakan sangat erat kaitannya dengan kehidupan petani di pedesaan yang sebagian besar melakukan kegiatan usahatani tanaman mgan dan 
hasil limbah pertanian untuk pakan ternak. Keadaan peternakan di wilayah kecamatan Umbulsari terdiri dari beberapa sub bab yaitu :

(1) Jenis dan Populasi Ternak. Jenis dan populasi ternak di wilayah kecamatan Umbulsari pada tahun 2012 - 2016, yang dipelihara oleh penduduk dibagi dua kelompok besar yaitu kelompok ruminansia dan kelompok unggas. Kelompok ruminansia tediri dari sapi potong, kerbau, kambing dan domba, sedangkan untuk kelompok unggas terdiri dari ayam ras pedaging dan ayam buras.

Keadaan jenis dan populasi ternak di wilayah kecamatan Umbulsari disajikan dalam Tabel. 1.

Tabel.1. Jenis dan Populasi Ternak di Wilayah Kecamatan Umbulsari (2016).

\begin{tabular}{|c|l|c|c|c|c|c|c|}
\hline \multirow{2}{*}{ No } & \multirow{2}{*}{ Jenis Ternak } & \multicolumn{5}{|c|}{ Tahun } & \multirow{2}{*}{$\mathrm{R}(\%)$} \\
\cline { 3 - 7 } & & 2012 & 2013 & 2014 & 2015 & 2016 & \\
\hline 1 & Sapi Potong & 9023 & 9768 & 10378 & 11973 & 14675 & 6,58 \\
2 & Kerbau & 120 & 139 & 169 & 187 & 205 & 10,04 \\
3 & Kambing & 2075 & 2345 & 2678 & 2998 & 3215 & 11,59 \\
4 & Domba & 435 & 485 & 548 & 583 & 612 & 8,96 \\
5 & Ayam Ras & 40000 & 45000 & 52500 & 57500 & 65000 & 12,93 \\
6 & Ayam Buras & 19.250 & 20.550 & 22.200 & 35.725 & 39.950 & 21 \\
\hline
\end{tabular}

Sumber : Dinas Peternakan Kabupaten Jember (2016).

Tabe1.1. tersebut di atas menunjukkan bahwa selama lima tahun terakhir populasi sapi potong paling banyak diantara kelompok ternak ruminansia lainnya kemudian kambing, domba dan yang paling sedikit adalah Kerbau. Populasi kerbau baik di wilayah kecamatan Umbulsari, maupun kabupaten Jember, bahkan propinsi Jawa Timur, merupakan kelompok ternak ruminansia yang paling sedikit dibandingkan dengan lainnya seperti sapi, kambing dan. domba, karena tenaga untuk membajak lahan di wilayah Jawa Timur umumnya menggunakan tenaga kerja sapi tidak menggunakan kerbau.

Namun demikian populasi kambing selama lima tahun terakhir kenaikkannya lebih cepat dibandingkar dengan kelompok ruminansia lainnya seperti kerbau, domba dan sapi potong. Di duga penyebabnya adalah ternak kambing tersebut digunakan oleh petani sebagai tabungan sangat dominan karena kambing atau domba mudah untuk di tukar atau di jual. 


\section{b. Keadaan Pola tanam}

Usahatani yang dilakukan di wilayah kecamatan Umbuilsari hampir seluruhnya merupakan usahatani lahan sawah dan tegalan, yaitu ushatani yang semata-mata menggantungkan tersedianya air hujan untuk pemenuhan kebutuhan pengairannya. Usahatani tersebut terdiri dari usahatani jagung, ketela pohon, ketela rambat dan tebu yang ditanam baik secara tunggal maupun secara tumpangsari. Usahatani lahan sawah di daerah persawahan. Usahatani yang dilakukan adalah tanaman padi dan diteruskan dengan tanaman jagung. Tanaman lain seperti kedelai, ketela rambat, kacang hijau dan kacang tanah, sedikit untuk ditanam.

Beberapa jenis Pola Tanam di Kecamatan Umbulsari adalah sebagai berikut :

A) Lahan Sawah ; 1) Padi - Padi

2) Padi - Jagung 2

B) Tegalan : : 1) Ketela Pohon - Jagung 2

2) Jagung 1 - Jagung 2

3) Tebu

Keadaan pola tanam di wilayah kecamatan Umbulsari pada lahan tegalan secara umum ada 3 macam dan lahan sawah ada 2 macam pola tanam. Sedangkan jadual kegiatan usahatani ada dua musim yaitu musim tanam I (pertama) atau musim hujan yaitu pada bulan akhir Oktober atau awal November sampai akhir Januari atau awal Februari dan musim tahun II (kedua) yaitu pada bulan awal Februari sampai akhir bulan Mei atau awal Juni.

\section{Analisis Biaya, Penerimaan dan Pendapatan}

\section{a. Komponen Biaya Usahatani dan Usaha Sapi Potong}

Komponen biaya usahatani tanaman dan usaha sapi potong dalam berbagai pola tanam di lokasi penelitian selama satu tahun dapat dilihat pada Tabel.2. 
Tabel.2. Komponea Biaya Usahatani Tanaman dan Usaha Sapi Potong Dengan Berbagai Pola Tanam Selama Satu Tahun (Rupiuh)

\begin{tabular}{|c|c|c|c|c|c|c|}
\hline \multirow{2}{*}{ No } & \multirow{2}{*}{ Uraian } & \multicolumn{5}{|c|}{ Macam Pola Tanam } \\
\hline & & I & II & III & IV & $\mathrm{V}$ \\
\hline I & USAHA TANI & & & & & \\
\hline A & Macam Biaya & & & & & \\
\hline 1 & Pajak Tanah & $125.950,-$ & $150.700,-$ & $140.950,-$ & 140.000,- & $365.000,-$ \\
\hline 2 & Pengairan & $575.000,-$ & $460.000,-$ & $350.000,-$ & 360.000,- & $685.000,-$ \\
\hline 3 & Sewa Tanah & 5.477.000,-- & 4.774.000,- & $3.787 .000,-$ & 4.300.000,- & 6.900.000,- \\
\hline 4 & Penyusutan Alat & $770.000,-$ & 790.000,-- & 795.000,- & $775.000,-$ & 175.000,- \\
\hline 5 & Benih & 1.140.000,- & 1.000.000,- & $800.000,-$ & 1.000.000,- & 1.500.000,- \\
\hline 6 & Pestisida & 4.060.000,- & 3.120.000,- & 1.950.000,- & $2.050 .000,-$ & $2.950 .000,-$ \\
\hline 7 & Pupuk & 4.540.000,- & 2.700.000,- & $2.400 .000,-$ & $2.450 .000,-$ & $8.350 .000,-$ \\
\hline 8 & Tenaga Kerja & 5.950.000,- & $5.100 .000,-$ & 3.950.000,- & $3.800 .000,-$ & 10.750.000,- \\
\hline 9 & Sewa Traktor & 2.400.000,- & 1.300.000,- & $450.000,-$ & $350.000,-$ & 65.000.000,- \\
\hline & Sub Total & 24.747 .950 & 19.293 .950 & 15.337.950 & 14.725 .000 & 96.750.000,- \\
\hline & & & ,- & ,- & ,- & \\
\hline II & USAHA SAPI & & & & & \\
\hline & POTONG & & & & & \\
\hline B. & Macam Biaya & & & & & \\
\hline 1 & Penyusutan & $85.000,-$ & & & & $120.000,-$ \\
\hline 2 & Kandang & $50.000,-$ & $90.000,-$ & $95.000,-$ & 100.000,- & $45.000,-$ \\
\hline 3 & Penyusutan Alat & 7.100.000.- & $45.000,-$ & $60.000,-$ & $55.000,-$ & 7.300.000,- \\
\hline 4 & Bibit Sapi Potong & 1.817.000,- & 6.950.000,- & 7.150.000,- & 7.200.000,- & $1.800 .000,-$ \\
\hline 5 & Hijauan Pakan & 1.100.000,- & 1.917.000,- & $1.850 .000,-$ & 1.800.000,- & 1.250.000,- \\
\hline 6. & Pakan Penguat & $400.000,-$ & 1.150.000,- & 1.250.000,- & 1.300.000,- & $350.000,-$ \\
\hline & Obat-obatan & 10.452 .000 & $350.000,-$ & $250.000,-$ & $300.000,-$ & $10.865 .000,-$ \\
\hline & Sub total & & 10.502 .000 & 10.405 .000 & 10.755 .000 & \\
\hline & & &, & ,- & ,- & \\
\hline
\end{tabular}

Komponen biaya usahatani tanaman padi 1 - padi 2 (pola tanam 1) dengan denngan usaha sapi potong pembibitan per hektar per ekor adalah Rp 24.747.950,untuk usahatani dan $\mathrm{Rp}$ 10.452.000,- untuk usaha sapi potong sehingga total biaya usahatani tanaman dan usaha sapi potong sebesar Rp 35.199.950,-, Komponen biaya usahatani tanaman padi 1 - jagung 2 (pola tanam 2) dengan dengan usaha sapi potong pembibitan per hektar per ekor adalah Rp 19.293.950,- untuk usahatani dan Rp 10.502.000,- untuk usaha sapi potong sehingga total biaya usahatani tanaman dan 
usaha sapi potong sebesar Rp 29.795.950.000,-. Komponen biaya usahatani tanaman Ketela Pohon 1 - Jagung 2 (pola tanam 3) dengan denngan usaha sapi potong pembibitan per hektar per ekor adalah Rp 15.337.950.000,- untuk usahatani dan Rp 10.405.000,- untuk usaha sapi potong sehingga total biaya usahatani tanaman dan usaha sapi potong sebesar Rp 25.742.950,-. Komponen biaya usahatani tanaman Jagung 1 - Jagung 2 (pola tanam 4) dengan denngan usaha sapi potong pembibitan per hektar per ekor adalah Rp 14.725.000,- untuk usahatani dan Rp 10.755.000,untuk usaha sapi potong sehingga total biaya usahatani tanaman dan usaha sapi potong sebesar Rp 25.480.000,-. Komponen biaya usahatani tanaman tebu (pola tanam 5) dengan denngan usaha sapi potong pembibitan per hektar per ekor adalah Rp 96.750.000,- untuk usahatani dan Rp 10.865.000,- untuk usaha sapi potong sehingga total biaya usahatani tanaman dan usaha sapi potong sebesar Rp 107.615.000,-. Darri hasil penelitian menunjukkan bahwa pada pola tanam 5 yaitu tanaman tebu dengan usaha sapi potong biaya paling tinggi dibandingkan dengan pola tanam lainnya, hal ini dikarenakan pada usahatani tebu memerlukan biaya yang tinggi karena biaya produksi memerlukan dana yang besar seperti pengolahan lahan, sewa tanah dan pupuk an organik (Semaoen, 2006)

\section{b. Penerimaan Usahatani Tanaman dan Usaha Sapi Potong}

Penerimaan usahatani tanarnan dan usaha sapi potong yaitu hasil produksi tanaman misalnya hasil dari ketela pohon, jagung, tebu dan ditambah dari hasil penjualan sapi, hasil dari tenaga kerja sapi dan hasil panjualan kotoran sapi.

Tabel. 3. Penerimaan Usahatani Tanaman dan Usaha Sapi Potongdengan Berbagai Pola Tanam Selama Satu Tahun (Rupiah)

\begin{tabular}{|l|l|l|l|l|}
\hline \multirow{2}{*}{ No } & \multicolumn{1}{|c|}{ Macam Pola Tanam } & \multicolumn{3}{c|}{ Penerimaan } \\
\cline { 3 - 5 } & & \multicolumn{1}{c|}{ Usahatani } & \multicolumn{1}{c|}{ Sapi Potong } & Jumlah \\
\hline 1. & Padi 1- Padi 2 & $36.450 .000,-$ & $14.770 .000,-$ & $51.220 .000,-$ \\
2. & Padi 1 dan Jagung 2 & $28.620 .000,-$ & $14.350 .000,-$ & $42.970 .000,-$ \\
3. & Ketela Pohon dan jagung 2 & $24.575 .000,-$ & $14.650 .000,-$ & $39.225 .000,-$ \\
4. & Jagung 1 dan Jagung 2 & $26.780 .000,-$ & $14.800 .000,-$ & $41.580 .000,-$ \\
5. & Tebu & $110.450 .000,-$ & $14.900 .000,-$ & $125.350 .000,-$ \\
\hline & Rata-rata & $45.375 .000,-$ & $14.694 .000,-$ & $60.069 .000,-$ \\
\hline
\end{tabular}

Penerimaan dari hasil usahatani pola tanam 1 sebesar Rp 36.450.000,- dan usaha sapi potong pembibitan sebesar Rp 14.770.000,- sehingga jumlah penerimaan sebesar Rp 51.220.000,- per hektar per satuan ternak ; penerimaan dari hasil 
usahatani pola tanam 2 sebesar 28.620.000,- dan usaha sapi potong sebesar Rp 114.350.000,-sehingga jumlah penerimaan sebesar Rp 42.970.000,-; penerirnaan dari hasil usahatani pola tanam 3 sebesar Rp 24.575.0009,- dan usaha sapi potong per satuan ternak sebesar Rp 14.650.000,- sehingga jumlah penerimaan sebesar Rp39.225.000--; dari hasil usahatani pola tanam 4per hektar sebesar Rp 26.780.000,dan usaha sapi potong per satuan ternak sebesar Rp 14.800.000,- sehingga jumlah penerimaan sebesar Rp 41.580.000,-; penerimaan dari hasil pola tanam 5 per hektar sebesar 110.450.000,- dan usaha sapi potong per satuan ternak sebesar Rp 14.900.000,-sehingga jumlah penerimaan sebesar Rp 125.350.000,- dan rata-rata penerimaan usahatani semua pola tanam rata-rata per hektar sebesar Rp 45.375.000,- dan usaha sapi rata-rata per satuan ternak sebesar Rp 14.694.000,--sehingga jumlah penerimaan sebesar Rp 60.069.000,-.

\section{c. Pendapatan Usahatani Tanaman dan Usaha Sapi Potong}

Pendapatan usahatani tanaman pangan dan usaha sapi potong adalah penerimaan dari hasil usahatani tanaman dan usaha sapi potong dikurangi biayabiaya untuk kegiatan usahatani tanaman dan usaha sapi potong. Pendapatan usahatani tanarnan pangan dan usaha sapi potong selama satu tahun dapat disajikan pada Tabel. 4 .

Tabel. 4. Pendapatan Usahatani Tanaman dan Usaha Sapi Potong Selama Satu tahun (Rupiah)

\begin{tabular}{|l|l|c|c|c|}
\hline \multirow{2}{*}{ No } & \multicolumn{2}{|c|}{ Macam Pola Tanam } & \multicolumn{3}{c|}{ Pendapatan } \\
\cline { 3 - 5 } & & Usahatani & Sapi Potong & Jumlah \\
\hline 1. & Padi 1- Padi 2 & $11.702 .000,-$ & $4.318 .000,-$ & $16.020 .000,-$ \\
2. & Padi 1 dan Jagung 2 & $9.325 .000,-$ & $3.848 .000,-$ & $13.173 .000,-$ \\
3. & Ketela Pohon1 dan jagung 2 & $9.237 .000,-$ & $4.245 .000,-$ & $13.482 .000,-$ \\
4. & Jagung 1 dan Jagung 2 & $12.325 .000,-$ & $4.045 .000,-$ & $16.370 .000,-$ \\
5. & Tebu & $13.700 .000,-$ & $4.035 .000,-$ & $17.735 .000,-$ \\
\hline & Rata-rata & $11.257 .800,--$ & $4.098 .200,-$ & $15.356 .000,-$ \\
\hline
\end{tabular}

Hasil penelitian menunjukkan bahwa pendapatan dari hasil usahatani pola tanam 1 sebesar Rp 11.702.000,- dan usaha sapi potong per satuan ternak sebesar Rp 4.318.000,- sehingga jumlah pendapatan Rp 16.020.000,- sedangkan pendapatan usahatani pola tanam 2per hektar sebesar Rp 9.325.000,- dan usaha sapi potong per 
satuan ternak sebesar R:p 3.848.000,- sehingga jumlah pendapatan sebesar Rp 13.173.000,-.Pendapatan dari usahatani pola tanam 3 per hektar sebesar 9.237.000,dan usaha sapi potong per satuan ternak sebesar Rp 4.245.000,- sehingga jumlah pendapatan Rp 13.482.000,-. pendapatan dari hasil usahatani pola tanam 4 sebesar Rp 12.325.000,- dan usaha sapi potong per satuan ternak sebesar Rp 4.045.000,sehingga jumlah pendapatan Rp 16.370.000,- pendapatan dari hasil usahatani pola tanam 5 sebesar Rp 13.700.000,- dan usaha sapi potong pembibitanper satuan ternak sebesar Rp 4.035.000,- sehingga jumlah pendapatan Rp 17.735.000,-

\section{d. Imbangan Penerimaan dan Biaya Usahatani dan Usaha Sapi Potong}

Imbangan anatara penerimaan dan biaya usahatani yaitu jumlah penerimaan dari hasil usahatani dibagi dengan biaya-biaya yang dikeluarkan untuk kegiatan usahatani, sehingga akan ditemukan nilai $\mathrm{R} / \mathrm{C}$ ratio.

Tabel. 5. Penerimaan dan biaya Usahatani Tanaman Selama Satu Tahun (Rupiah) Pada Usaha Sapi Potong Pembibitan

\begin{tabular}{|l|l|c|c|c|}
\hline No & \multicolumn{1}{|c|}{ Macam Pola Tanam } & Penerimaan & Biaya & R/C Ratio \\
\hline 1. & Padi 1- Padi 2 & $36.450 .000,-$ & $24.747 .950,--$ & 1,47 \\
2. & Padi 1 dan Jagung 2 & $28.620 .000,-$ & $19.294 .900,-$ & 1,48 \\
3. & Ketela Pohon1 dan jagung 2 & $24.575 .000,-$ & $15.337 .950,-$ & 1,60 \\
4. & Jagung 1 dan Jagung 2 & $26.780 .000,-$ & $14.725 .000,-$ & 1,82 \\
5. & Tebu & $110.450 .000,-$ & $104.875 .000,-$ & 1,05 \\
\hline & Rata-rata & $45.375 .000,-$ & $35.796 .160,-$ & 1,27 \\
\hline
\end{tabular}

Pada Tabel. 5. tersebut di atas nampak bahwa nilai $\mathrm{R} / \mathrm{C}$ ratio untuk masingmasing usahatani pola tanam 1 sebesar 1,47 , pola tanam 2 sebesar 1,48 , pola tanam 3 sebesar 1,60, pola tanam 4 sebebsar 1,82 dan pola tanam 5 sebesar 1,05. Hasil penelitian menunjukkan bahwa rata-rata nilai $\mathrm{R} / \mathrm{C}$ ratio untuk usahatani tanaman sebesar 1,27. Hasil penelilian menunjukkan bahwa nilai R/C ratio menunjukkan angka positip yang berarti bahwa petani masih memperoleh keuntungan walaupun nilainya kecil. Menurut Clive Guy, Lien K. sabur, P. Simanjuntak dan P. F. Maspaitella (1988) bahwa usaha tersebut layak untuk diusahakan. deskriptif yaitu dengan menghitung rata-rata pendapatan. Anita Ariani Murpa, Nurani Sirajuddin, dan Ikrar Mohammad Saleh (2015) Hasil penelitian menunjukkan bahwa pendapatan peternak sapi potong pola bagi hasil teseng yang ada di desa lempang, kecamatan tanete riaja, kabupaten barru dengan rata-rata pendapatan per tahun yang 
diperoleh peternak (pa'teseng) dengan kepemilikan 8 ekor yaitu Rp. 21.901.667 dengan R/C 2,9, kepemilikan 7 ekor Rp. 20.420 .417 dengan R/C 3,1, kepemilikan 5 ekor Rp. 12.079.444 dengan R/C 2,3, kepemilikan 4 ekor Rp. 9.356.500 dengan R/C 2,0, kepemilikan 3 ekor Rp. 7.232.917 dengan R/C 1,8, kepemilikan 2 ekor Rp. 5.201.146 dengan R/C 1,8, dan kepemilikan 1 ekor Rp. 2.507.500 dengan R/C 1,8 .

\section{KESIMPULAN DAN SARAN}

\section{Kesimpulan}

Dari analisis dan pembahasan tersebut di atas, maka dapat disimpulkan sebagai berikut :

1) Pola tanam 5 yaitu tanaman tebu dengan usaha sapi potong biaya paling tinggi dibandingkan dengan pola tanam lainnya yaitu per hektar per ekor adalah Rp 96.750.000,- untuk usahatani dan Rp 10.865.000,- untuk usaha sapi potong sehingga total biaya usahatani tanaman dan usaha sapi potong sebesar Rp 107.615.000,-, hal ini dikarenakan pada usahatani tebu memerlukan biaya yang tinggi karena biaya produksi memerlukan dana yang besar seperti pengolahan lahan, sewa tanah dan pupuk an organic.

2) Pola tanam 5 yaitu tanaman tebu dengan usaha sapi potong penerimaan paling tinggi yaitu penerimaan dari hasil pola tanam 5 per hektar sebesar 110.450.000,- dan usaha sapi potong per satuan ternak sebesar Rp 14.900.000,-sehingga jumlah penerimaan sebesar Rp 125.350.000,-

3) Pendapatan dari hasil usahatani pola tanam 5 sebesar Rp 13.700.000,- dan usaha sapi potong pembibitan per satuan ternak sebesar Rp 4.035.000,sehingga jumlah pendapatan $\mathrm{Rp}$ 17.735.000,- yang merupakan pendapatan paling tinggi.

4) Tingkat imbangan penerimaan dan biaya pada pola tanam 4 sebebsar 1,82 merupakan paling tinggi.

\section{Saran}

Biaya dalam usahatani yang cukup besar sedangkan petani sulit dalam memperoleh dana tersebut, maka pemerintaperlu memberikan bantuan modal usaha yang diberikan kepada petani tanpa anggunan serta aturan yang rumit dengan biaya bunga pinjaman yang sangat rendah dan dapat terjangkau oleh petani. 


\section{DAFTAR PUSTAKA}

Anita Ariani Murpa, Nurani Sirajuddin, dan Ikrar Mohammad Saleh, 2016. Analisis Pendapatan Peternak Usaha Sapi Potong Pada Pola Bagi Hasil Teseng Di Desa Lempang, Kecamatan Tanete Riaja, Kabupaten Barru. Laporan Penelitian Fakultas Peternakan Universitas Hasanudin, Makasar Jl. Perintis Kemerdekaan Km. 10 Kampus Unhas Tamalanrea Telp/Fax (0411) 587 Makassar 90245.

Semaoen, I dan S.M. Kiptiyah (2006). Distribusi Pendapatan dan Kemiskinan di Desa Miskin Jawa Timur, Jurnal Penelitian ilmu-ilmu Sosial. Agustus, Vol.9(2) Lembaga Penelitian Universitas Brawijaya. Malang.

Singarimbun. M dan S. Efendi, 1982. Metode Penelitian Survai. PT Pustaka. Lembaga Penelitian Pendidikan dan Penerangan Ekonomi Social (LP3ES) Indonesia Jakarta. 